International

Medical Society

http://imedicalsociety.org

\title{
Man's Health at Home: an Integrative Review
}

\section{Abstract}

Objective: To analyze the scientific literature about home care in the context of man's health.

Methods: A integrative review carried out in August and September 2015, consisting of 39 articles indexed in the databases SciELO, MEDLINE, LILACS, and BDENF IBECS.

Results: The results converged into three categories - home care to the man with chronic problems, granted by formal and informal caregivers; the political and economic, social and educational mismanagement for the caregiver and health care, in man's home care; improvement in health and human quality of life in home care.

Conclusion: it becames clear that the characteristics and health problems residing in assisted men are common in Brazil and other countries in addition to the marked improvement in health and quality of life of the man who is assisted at home, compared to its hospital stay.

\section{Introduction}

The Unified Health System (SUS) emerged in Brazil in order to create equitable conditions and quality of health opportunities for the population, from its principles of universality, comprehensiveness and equity. Through programs and policies, based on the uniqueness of each population group, the Ministry of Health $(\mathrm{MOH})$, startled by the harm to men's health due to their greater vulnerability to disease, especially chronic, disabling conditions from external causes and high rates of mortality, launched in 2008 the National Policy for Integral Attention to Men's Health (PNAISH). This policy is based on the humanization, qualification and change the male perception in the care of their own health and that of their families [1].

Refering to chronic diseases and disabilities, it is the interface with the home care, which is a form of health care to substitute character or
Jocelly de Araújo Ferreira1, Roseni Rosângela de Sena ${ }^{2}$

1 Doctoral Candidate, post graduation program in Nursing by Minas Gerais Federal University, UFMG. Docent at Campina Grande Federal University, UFCG. Campina Grande, Brazil.

2 Doctor in Nursing by São Paulo University, USP. Principal at Minas Gerais Public Health School. Belo Horizonte, Brazil.

\section{Contact information:}

Jocelly de Araújo Ferreira.

Address: Edvaldo Bezzerra Cavalcante Pinho Street, 320, Apartment 102, Cabo Branco, Paraíba, Brasil.

Đ jocellyaferreira@hotmail.com

Keywords

Men's Health; Home Nursing; Homebound Persons; Continuity of Patient Care; Home Care Services. 
complement to an existing one, customized by actions to promote and protect the health, treatment diseases and rehabilitation at home, which in Brazil is through the Home Care Service (SAD), represented by the Program Best at Home [2]. This assistance aims to: accelerate recovery through approaching home environment, reduce the risk of nosocomial infections, reduce costs of hospitalizations and readmissions, provide a more human environment to the user, increase turnover and free up beds, integrate professional -family user [3].

Even before the PNAISH, men are still seen as subjects who little care for their health or who take measures to prevent and control diseases, which is quickly reflected in morbidity and mortality rates of the male population, increasing costs and the need for secondary, tertiary and home assistance. This condition rushes the growth in government and social participation, which is not so contemporaneously noticed. Thus, the present study sought to investigate how men with health problems are being assisted at home by the following guiding question: how is happening to men health in terms of home care? In order to answer this question, it is aimed to review and analyze, through a systematic review, as shown home care in the men's health context.

\section{Method}

The methodological approach used in this qualitative research was the literature of integrative review of scientific literature concerning home care to men, in the period between 2005 and 2015. The literature integrative review constitutes in search of studies through a planned approach and synthetic, answering a question. It was used the methodology from an integrative review to capture advances in the production of knowledge on the subject and answer the question. This methodology provides a review that identifies, selects, evaluates and critically analyzes the productions, seizing the evidence in order to facilitate the taking of evidence-based decisions.
The integrative literature in general and in order to avoid bias, follow the following steps for your design: clear definition of the object of interest to be investigated, which is done through the elaboration of guiding question; search or sampling in the literature; the data collection; critical analysis of the included studies; the discussion of the results and the presentation of the integrative review. Also it is imperative for review, to assign a classification of the level of evidence and grade of recommendation, the final set of selected items $[4,5]$.

By contextualization of this type of study, this review took place in August and September 2015 and followed the following path: delimited to the object of interest through the problematical issue defined by - as is happening to human health in level of home care?; then it was selected the descriptors that best respond to study the object, the selection occurred by accessing the DeCS/MeSH websties and reading concepts on them. To develop searching strategies of scientific production, the descriptors were used, in Portuguese, English and Spanish, according to the following intersections: human health AND home care; home patients AND human health; hospital services home care AND human health; continuity of care to the patient AND human health; home care services AND human health.

Defined the criteria for inclusion and exclusion of publications to compose the scope of the study: full articles; indexed in the Scientific Electronic Library Online databases (SciELO), Medical Literature Analysis and Retrieval System Online (MEDLINE), Latin American and Caribbean Health Sciences (LILACS), Nursing Database (BDENF) and Bibliographical Index Spanish Health Sciences (IBECS); understood in a time frame of 10 years (2005-2015), limited to male and published in Portuguese, English or Spanish.

After defining the criteria, we went to Virtual Health Library (VHL) and the Journal Portal Higher Education Personnel Improvement Coordination (CAPES), using 10 defined search strategies, all reviewed by two librarians. When performing this screening yielded 61,311 articles, as follows: 
55,961 in MEDLINE, LILACS 1,834,902 in BDENF, 1054 in IBECS, 1,560 in SCIELO and other bases; of these, 48,936 in English, 2,046 in Spanish, 3,422 in Portuguese and 6,907 in other languages. Sequentially, we used the inclusion criteria, totaling 815 items, including: 649 in MEDLINE, 26 in LILACS seven in IBECS, 133 in SCIELO and none in BDENF; of these, 700 in English, 65 in Spanish and 50 in Portuguese.

From these selected items, the Repeated ones were excluded in more than one database, resulting in a quantitative production 10 duplicates. Made to read the abstracts of the articles, excluding those who did not fit the investigated object, and the outcome of 60 articles, of which 37 in MEDLINE, one in LILACS, 22 in SCIELO, none in BDENF and IBECS; of these, 33 in English, four in Spanish, 23 in Portuguese. All 60 articles were retrieved in databases and carefully read in their entirety by two researchers, an expert in systematic and integrative review methodology of literature and other specialist in the study of the object. During the examination of these articles to carefully read the full text of productions included in the review was performed.

After the careful reading of the publications, 21 articles were rejected and 39 accepted to understand the set of definitive studies in the review. These studies were numbered and organized by year, authors, language, journal, type of publication, title, objectives, methodological theoretical framework, bias (selection, performance, detection, reporting and other bias) [6, 7], synthesis and selection of quotations. In these studies, we used the PRISMA recommendations and has also applied a classification on the level of evidence, assessing the quality of articles [6]. By applying this classification, it was observed that five articles obtained level 3 of evidence six articles level 4:28 articles level 5 .

All articles selected and included in this integrative review were organized in a table and described in detail. Through the convergence of the findings from the selected publications, after careful analysis of their content, the articles were grouped into three categories, to proceed with the discussion.

(Figure 1)

Figure 1: Flowchart of selection of studies found. João Pessoa, PB, Brazil.

BVS e Periodic portals CAPES

61311 search strategy

MEDLINE: 55961

LILACS: 1834

BDENF: 902

IBECS: 1054

SCIELO and other 1560

Relevancy Test I
\[ \]
Database
Repeated:
10

Relevancy

815 publishings

Test II (Reading the titles and abstracts) MEDLINE: 649

LILACS: 26

BDENF: 0

IBECS: 7

SCIELO: 133

Excluded Studies: 755

60 recovered publishings (full article reading)

MEDLINE: 37

Relevancy Test III

LILACS: 1

BDENF: 0

IBECS: 0

SCIELO: 22

39 Selected studies to

Excluded composse the sample studies: 21

Classification of the level of evidence

- 05 articles with level 3 evidency

- 06 articles with level 4 evidency

- 28 articles with level 6 evidency

- Insertion of Relevancy tests

- Excluded stduies

- Included data

Source: Research data, in 2015. 


\section{Results}

The publications were selected and analyzed in summary in Table 1 and characterized the order of articles, authors, year, study design, language, publishing periodic and qualis.

The analysis allowed to evidence that most publications, 28 articles, has more than three co-author- ships and only three have single authorship. The year of the most prominent publications directed to the issue of health home man, in the last 10 years were 2010 and 2013, with the same proportion of seven articles, sequenced by 2011 with six articles. Regarding the publication language, the Portuguese deserved notoriety, with 20 articles, however,

Table 1. Characterization of the selected productions for review, according to the number, authors, year, study design, language, journal and qualis. João Pessoa, PB, Brazil, in 2015.

\begin{tabular}{|c|c|c|c|c|c|c|}
\hline $\mathbf{N}^{\circ}$ & Authors & Year & Studies Design & Language & Períodic & Qualis \\
\hline 01 & Toki et al. & 2008 & Qualitative and Case reports & English & Arch Phys Med Rehabil & B1 \\
\hline 02 & Kaffashian et al. & 2011 & Prospective Multicenter Cohort & English & Age and Ageing & A2 \\
\hline 03 & Teno et al. & 2013 & Retrospective cohort & English & Jama & C \\
\hline 04 & Huijzen; Van Staa & 2013 & Qualitative & English & $\begin{array}{l}\text { Scandinavian Journal of } \\
\text { Occupational Therapy }\end{array}$ & A2 \\
\hline 05 & Ansari et al. & 2009 & Observational cohort, comparative & English & Chronic Respiratory Disease & B1 \\
\hline 06 & Cheng et al. & 2012 & Qualitative & English & Public Health Nursing & A1 \\
\hline 07 & Tamir et al. & 2007 & Quantitative and comparative & English & Palliative Medicine & A2 \\
\hline 08 & Ettner et al. & 2008 & Cohort, Multicenter & English & AIDS Care & A2 \\
\hline 09 & Clinch; Brian Le & 2011 & Case report and literature review & English & Palliative Medicine & A2 \\
\hline 10 & Freitas; Meneghel & 2008 & $\begin{array}{c}\text { Case report and participant } \\
\text { observation }\end{array}$ & Portuguese & Texto Contexto Enferm. & $A 2$ \\
\hline 11 & Thumé et al. & 2010 & Transversal population base. & Portuguese & Rev Saúde Pública & A2 \\
\hline 12 & Brondani CM et al. & 2013 & $\begin{array}{c}\text { Quantitative, transversal and } \\
\text { descriptive }\end{array}$ & Portuguese & Rev Enferm UFSM & B3 \\
\hline 13 & Fripp et al. & 2012 & Quantiqualitative & Portuguese & $\begin{array}{l}\text { Epidemiologia e Serviços de } \\
\text { Saúde }\end{array}$ & B2 \\
\hline 14 & Campos; Lara Silva & 2013 & Descriptive and exploratory & Portuguese & Rev Min Enferm & B2 \\
\hline 15 & Neves et al. & 2013 & Quantiqualitative & Portuguese & Psicologia Hospitalar & B3 \\
\hline 16 & Marques; Freitas & 2009 & $\begin{array}{l}\text { Qualitative, descriptive and } \\
\text { evaluative }\end{array}$ & Portuguese & Rev Esc Enferm USP & B2 \\
\hline 17 & Machado; Scramin & 2010 & Descriptive and exploratory & Portuguese & Rev Esc Enferm USP & B2 \\
\hline 18 & Martelli et al. & 2010 & Descriptive and retrospective & Portuguese & $\begin{array}{l}\text { Physis - Revista de Saúde } \\
\text { Coletiva }\end{array}$ & B1 \\
\hline 19 & Parenti et al. & 2005 & Transversal & Portuguese & $\begin{array}{l}\text { Epidemiologia e Serviços de } \\
\text { Saúde }\end{array}$ & B2 \\
\hline 20 & Bajotto et al. & 2012 & $\begin{array}{c}\text { Quantitative, descriptive and } \\
\text { transversal }\end{array}$ & Portuguese & Rev HCPA & B3 \\
\hline 21 & Lacerda et al. & 2011 & Transversal, Analytical PADI & Portuguese & Rev. Bras. Geriatr. Gerontol & B2 \\
\hline 22 & Saevareid et al. & 2007 & Transversal & & Aging \& Mental Health & $A 2$ \\
\hline
\end{tabular}




\begin{tabular}{|c|c|c|c|c|c|c|}
\hline $\mathbf{N}^{\circ}$ & Authors & Year & Studies Design & Language & Períodic & Qualis \\
\hline 23 & Sorbye et al. & 2010 & Cohort & English & $\begin{array}{l}\text { Journal of Multidisciplinary } \\
\text { Healthcare }\end{array}$ & B1 \\
\hline 24 & Ruiz-Mirallesa et al. & 2007 & Descriptive & Spanish & Enfermería Clínica & B1 \\
\hline 25 & Chayamiti, Caliri & 2010 & Quantitative,descriptive, transversal & Portuguese & Acta Paul Enferm & B3 \\
\hline 26 & Duval et al. & 2010 & Quantitative, prospective & Portuguese & $\begin{array}{l}\text { Revista Brasileira de } \\
\text { Cancerologia }\end{array}$ & B2 \\
\hline 27 & Gaspar et al. & 2007 & $\begin{array}{c}\text { Epidemiological, ecological, } \\
\text { descriptive }\end{array}$ & Portuguese & Rev Esc Enferm USP & B2 \\
\hline 28 & Almaawiy et al. & 2015 & Cohort of population-based & English & Palliative Medicine & A2 \\
\hline 29 & Rodriguez & 2013 & Quantitative & English & $\begin{array}{c}\text { European Journal of Public } \\
\text { Health }\end{array}$ & A2 \\
\hline 30 & Santana; Alves & 2014 & Descriptive & Portuguese & $\begin{array}{c}\text { Revista Eletrônica Gestão \& } \\
\text { Saúde }\end{array}$ & B4 \\
\hline 31 & Thumé et al. & 2011 & Cross with logistic regression & English & $\begin{array}{c}\text { American Journal of Public } \\
\text { Health }\end{array}$ & A1 \\
\hline 32 & Del Duca et al. & 2011 & Transversal of population-based & Portuguese & Rev Saude Publica & A2 \\
\hline 33 & Cavalcante et al. & 2013 & Qualitative and descriptive & Portuguese & Rev enferm UFSM & B3 \\
\hline 34 & Weinland & 2009 & phenomenological & English & $\begin{array}{c}\text { American Journal of Men's } \\
\text { Health }\end{array}$ & B2 \\
\hline 35 & Mullen & 2009 & Case Report & English & Home Healthcare Nurse & B2 \\
\hline 36 & Jagger et al. & 2011 & Quantitative & English & BMC Geriatr & B1 \\
\hline 37 & Cattalini et al. & 2012 & $\begin{array}{l}\text { Descriptive, prospective and } \\
\text { longitudinal }\end{array}$ & Portuguese & Cuidarte. Enfermagem & B5 \\
\hline 38 & Maroldi et al. & 2012 & Descriptive & Portuguese & Cuidarte. Enfermagem & B5 \\
\hline 39 & Rumbak et al. & 2010 & Quantitative, Random sampling & English & Coll. Antropol & B2 \\
\hline
\end{tabular}

stands out the English with the amount of 18 articles published in this matter.

The journals kept heterogeneity in the area of public health, epidemiology and hospital. It was found that between these journals there are 10 international and 14 national, highlighting the Nursing School University of São Paulo magazine with three publications, bringing good emphasis on targeted Nursing studies. It is observed that most of the journals are indexed to a large scientific impact of databases and QUALIS established between A1 and B2.

Is worth stressing that the methodological design of higher frequency between the studies were cross-sectional quantitative, averaging 10 studies, followed by prospective cohort studies, retrospective or observational nine studies and less applicability in three articles in a quantiqualitative methodological design.

As regards biases found in the studies that comprised this systematic review, it appears that all the articles had high or low risk of developing bias and selection, performance, and endpoint detection or diagnosis report. Note that each item had two or more risk of bias, highlighting the selection and outcome often 29 items with selection bias and 12 outcome, perhaps grounded in the absence of randomization of the study sample that supported the article. 
It is imperative to point out that 10 studies understood in its development as a theoretical and/ or methodological, quote: free approach thematic analysis (8), Theory founded by Stauss and Cabin [9], constructionist perspective of the study of language and production of the philosopher's way Michel Foucault [10] theoretical model associations between hypotheses [11], risk assessment for UPP by Braden Scale [12], subjective global assessment produced by the patient [13], theory of basic human needs garden tools [14], the NANDA taxonomy [15], phenomenology [16] and self-care theory of Oren [17].

The results of published studies, as well as the following discussion, were structured into categories drawn from the convergence of its content, since the proposed objectives to the important findings. Articles bring in its scope the magnitude of men health thematic and home care, passing by content ranging from formal and informal caregivers of men with health care in your home until the implication of such assistance in improving the health and quality of life of these men.

Thus, they grouped into categories homogeneous content of productions, following listed and referenced by articles that constituted: Home care man with chronic problems, granted by formal and informal caregivers. The content of the articles [3, 8-12, 14, 15, 21-23, 25-29, 30-32, 34, 39] depicts how men with cardiovascular diseases, using mechanical ventilation, respiratory problems, example of chronic obstructive pulmonary disease (COPD), infectious diseases such as HIV, diseases such as depression and Alzheimer's disease, fractures and spinal cord injuries are taken care of at home.

The second category called is: the political and economic, social and educational mismanagement for the caregiver and health care, in home care to man. The content of the articles [9, 10, 16, 19, 20, $22,24,28,29-31,33-39]$ specifies that the social, economic and educational standards of caregivers interfere in how they provide care to men. These articles also confirm that the political and economic condition affects the way health services are structured to meet the man at his home.

The last category was entitled by: improving health and men's life quality in home care. The content of the articles [3, 13, 17, 21, 23, 25, 27, 29, 32, $35,36,40-46]$ emphasizes improving health and quality of human life, even for those who have a disease that threatens life, when watched in your home.

\section{Discussion}

From the results presented by articles of literature review, the analyzed categories which emerged in order to synthesize the contents found in the articles, in order to answer the question that guided this review:

\section{Men home care with chronic issues, granted by formal and informal caregivers}

Predominates in recovered articles the notion that the practices directed to men in the form of home care are related to people with chronic illnesses bearers. There are a variety of chronic medical conditions that can be treated successfully in households, with some differentiation with respect to the assistance provided by formal and informal caregivers [19-22].

Chronic diseases which demand home care have been described by: cardiovascular disease, Alzheimer's, dementia, depression, schizophrenia, stroke, degenerative neuropathies, fractures, osteomyelitis, varicose ulcers, polio sequelae and cardiac arrest, as well as cancers in terminal stage users [19-23]. It denotes that these men assisted at home have on average more than five comorbidities and at least two clinical diagnoses [21].

Some of the examined articles brought in its scope the profile of men who are assisted in their homes, characterizing them by: predominant age group between 61 and 89 years old, under 30 years a minority due to congenital causes or accidents, 
married or widowed, low education, low income and retired, living in suburbs, referred by the Family Health Strategy and hospitals sectors like cardiology [3, 20-27].

It was noticed, with the analyzed studies, that men in clinical conditions of high risk of destabilization require frequent care by formal caregivers - occupational therapy, nursing, physical therapy, medical and psychology - when compared to informal - children, wives and even neighbors [8, 19, 20, 27-31]. The assistance, when provided by informal caregivers, requires training, besides the particularity of the domiciles are close to the hospital services and lack of materials, equipment and supplies to care, and it is imperative to emphasize that the residences can be their own men or support, such as nursing homes and hostels, which are constant in countries like Canada and the United States of America [8, 24, 31].

The minimum care and intermediaries are the most frequent at home, quote: the nasoenteric survey (SNE), care of pressure ulcers (UPP), the aid for intestinal eliminations and intermittent bladder catheterization $[12,14,15,19,24]$.

Studies have shown evidence that men, when taken care at home with at least one visit per week of a caregiver, such as nursing, have shown improvement in their health status, equivalent to when treated in hospitals. The positive effects of home care is not noticeable only in improving the health of men, but in the relationship and the conditions of professionals in not going to hospitals and humanization of care [9, 11, 14, 26, 29, 32]. Therefore, home care offered to men with chronic problems, either formal or informal carers, brings considerable improvements and desirable health.

\section{The political and economic interference, social and educational for the caregiver and health care, in home care man}

Informal caregivers, also called home caregivers in various articles can be family members and/or people without specific training, who are hired for this purpose. It highlights the important role of informal caregivers, especially with regard to the spouse, who most often have low education, provides care without compensation and without the help of other family components, making the care burden, due to old age this caregiver and the cared, in which demand attention, physical and mental effort of those who watches [10, 19, 20, 22, 24, $28,33,34]$. However, among these caregivers, and not least, there are the children, who have paid work and only providing a day off to fully engage the caregiver function [28].

Home care, as referred to formal caregivers, should appreciate the multidisciplinary character of educational strategies, care diversity, evaluation and co-responsibility with the informal caregivers [16, $19,20,24,31]$.

The use of one or more technologies in the home is an axiom, represented by the continuous use of medication, mechanical ventilation, peritoneal dialysis, hemodialysis, SNE, indwelling urinary catheter, gastrostomy, tracheostomy, oxygen therapy, curative with surgical wounds, care UPP, stoma care, injections and environmental organization [10, 31, 33, 35].

The advent of home care has decreased the number of occupied beds and hospital costs in countries such as the UK $[29,36]$. In England and Wales increase is projected at $82 \%$ between 2010 and 2030, with demand of more than 630, 000 Home Care [37]. Despite the proven rise of home care, are perceived limitations in this type of assistance, requiring improvement in the quality of their services. These limitations have micro dimensions - patient characteristics - and macro - political, social and economic - and micro less impact when compared to macro $[9,28]$.

Among the macro dimensions, there is a difference in access to medical services, since in countries like the United States Medicaid program has less access to those who do not have private health 
insurance. In countries like Brazil and Spain, this statement becomes valid, because access to health and home services is proportional to family income, influencing the reception of formal, informal or mixed care and generating health inequities $[30,38]$. Even by the macro dimensions, there is the absence of home care policy to subsidize the compensation of informal care by formal, by transferring the family responsibility to government, which for now is complementary. It is noticed that there is potential in home care program, however, the weaknesses in the care and management are higher [10, 30]. In Brazil, the SUS, through the rehabilitation hospital network of institutions, act as support for home care; however, the reference health unit only act as material suppliers, not ensuring comprehensive care to people at home. It is emphasized that, in states like São Paulo, primary care remains acting in a disjointed way, justified by the lack of a municipal policy homecare able to support the structuring of health services [38, 39]. Thus, it is assumed that in Brazil home care still needs great discussions to formulate policies that truly promote home care.

\section{Improvement in health and Man quality of life in home care}

Based on the results of three studies, it was found that discharge from hospital to home, even in home care system, promotes improved health and quality of life of men. Regardless of the diagnosis that these men have and justifying the continuity of care, this practice at home has shown a reduction in mortality and in hospital returning $[27,29,40]$. Home care can be a wish of the patient, when it reaffirms its call to die at home, they are terminal patients. When at the end-stage condition, well assisted home environment and quality of care appears to be an ideal place for the end of life [13, 23, 36, 41, 42].

Quality of life (QOL) of men and family becomes better at home than in the hospital, as there is an evident improvement in vitality, psychosocial well- being, comfort and environmental safety, satisfaction with care received and offered, in a sense of freedom, peace and gratitude for being at home, not glimpse the suffering of others, the possibility of self-care, reducing risk factors, such as poor eating habits [3, 17, 21, 25, 32, 35, 43-46]. Thus, we highlight the attributes of home care to the male patient with chronic problems, when this care is practiced with ethics, safety, humanization and grounded in health policies.

\section{Conclusion}

This study allowed the analysis of the size of home care in the context of man health through an integrative review of scientific publications related to this thematic in Brazil and in other countries. It is emphasized that there were limitations in the development of this study, because men, in their large majority of articles were not the main object of research, being present in the characterization of the participants with women, which demonstrates the insufficient scientific approaches and specific attention to human health.

It was evident, with the articles analyzed, that home care to men is still in its infancy when it comes to perceive them in their uniqueness and considering its historical-cultural scenario. To investigate what the literature shows about this subject, it was noticed that the characteristics of the home assisted men are common, regardless of the country investigated, as well as health problems that led them to require formal or informal care at home. It was also evident that the home care involves understanding the family, domestic life and community are not isolated, but part of the educational dynamic, political and economic society as a whole.

The studies analyzed in their findings brought noticeable improvement in health and quality of life of men who are assisted at home compared to their hospital stay. Therefore reiterates the importance of studies that address the home care services 
targeted to men in their individuality, and research that emphasize the practical aspects of assistance to man in his home, as studies have focused more on emotional, psychological and on users and their caregivers wellbeing.

\section{References}

1. Brasil. Ministério da Saúde. Secretaria de Atenção à Saúde. Departamento de ações programáticas estratégicas. Política nacional de atenção integral à saúde do homem (Princípios e diretrizes). Brasília: MS, 2008.

2. Platel ICS, Batista PSS, Costa SFG, Freire MEM, Lopes MEL, Batista JBV, et al. Therapeutic Actions Promoted to Terminal Patient: Professional Experience at Home Care Service. Arch intern med. 2016;9(165):1-11.

3. Martelli DRB, Silva MS da, Carneiro JA, Bonan PRF, Rodrigues LHC, Martelli-Júnior H. Internação domiciliar: o perfil dos pacientes assistidos pelo Programa HU em Casa. Physis Rev Saúde Col. 2011; 21(1):147-57.

4. Souza MT, Silva MD, Carvalho R. Revisão integrativa: o que é e como fazer. Einstein. 2010; 8(1):102-6.

5. Pereira AL, Bachion MM. Atualidades em revisão sistemática de literatura, critérios de força e grau de recomendação de evidência. Rev Gaúcha Enferm. 2006;27(4):491-8.

6. Moher D, Liberati A, Tetzlaff J, Altman DG. Principais itens para relatar revisões sistemáticas e metanálises: a recomendação PRISMA. Epidemiol Serv Saúde. 2015; 24(2):335-42.

7. Botelho F, Silva C, Cruz F. Epidemiologia explicada: vieses. Acta Urológica. 2010; 47(3):47-52.

8. Van Huijzen S, Van Staa A. Chronic ventilation and social participation: experiences of men with neuromuscular disorders. Scan J Occup Ther. 2013; 20(3):209-16

9. Cheng JF, Huang XY, Lin MJ, Yang TC, Hsu YS. Intervening conditions of hospital: based home care for people with severe mental illness. Pub Health. 2012; 29(4):320-9.

10. Marques GQ, Freitas IBA. Experiência piloto de assistência domiciliar: idosos acamados de uma unidade básica de saúde, Porto Alegre, Brasil. Rev Esc Enferm USP. 2009; 43 (4): 825-32.

11. Saevareid HI, Thygesen E, Nygaard HA, Lindstrom TC. Does sense of coherence affect the relationship between self-rated health and health status in a sample of community-dwelling frail elderly people? Aging Ment Health. 2007; 11 (6):658-67.

12. Chayamiti EMPC, Caliri MHL. Úlcera por pressão em pacientes sob assistência dom iciliária. Acta Paul Enferm. 2010; 23 (1): 29 34.

13. Duval PA, Vargas BL, Fripp JC, Arrieira ICO, Lazzeri B, Destri K, et al. Caquexia em pacientes oncológicos internados em um programa de internação domiciliar interdisciplinar. Rev Bras Cancerol. 2010;56(2):207-12.
14. Santana CR. Estudo sobre os limites e possibilidades do programa de internação domiciliar em desospitalizar doentes portadores de doenças crônico degenerativas na regional de saúde do Paranoá. Rev Eletrôn G\&S. 2014; 5(1):37-46.

15. Cavalcante KMH, Figueirêdo Carvalho ZM, Garcia FMP. Diagnósticos de enfermagem aplicáveis a pessoas com paraplegia em fase inicial de reabilitação domiciliar. Rev Enferm UFSM. 2013; 3(2):238-47.

16. Weinland JA. The lived experience of informal African American Male caregivers. Am J Men's Health. 2009;3(1):16-24.

17. Mullen K. An older adult man who is unable to sleep: advocating self-care in home healthcare. Home Healthcare Nur. 2011; 29(1):22-5.

18. Melnyk BM, Fineout-Overholt E. Evidence-based practice in nursing \& healthcare: a guide to best practice. Philadelphia: Wolters Kluwer, Lippincott Williams \& Wilkins; 2011.

19. Freitas IBA, Meneghel SN. Artefatos de cuidado no domicílio como expressão de poder. Texto Contexto Enferm. 2008;17(2):358-64.

20. Thumé E, Facchini LA, Tomasi E, Vieira LAS. Assistência domiciliar a idosos: fatores associados, características do acesso e do cuidado. Rev Saúde Púb. 2010; 44(6):1102-111.

21. Neves RT, Laham CF, Aranha VC, Santiago A, Ferrari S, Lucia MCS. Envelhecimento e doenças cardiovasculares: depressão e qualidade de vida em idosos atendidos em domicílio. Psicol Hosp. 2013; 11(2):72-98.

22. Maroldi MAC, Ponte D, Roceti LC, Figueiredo RMD, Caliari JDS. Internação domiciliar: caracterização de usuários e cuidadores. CuidArte Enferm. 2012; 6(1):24-29.

23. Clinch $A$, Brian L. Withdrawal of mechanical ventilation in the home: A case report and review of the literature. Palliat Med. 2011; 25 (4): 378-81.

24. Campos CVS, Silva KL. Cateterismo vesical intermitente realizado pelos cuidadores domiciliares em um serviço de atenção domiciliar. Rev Min Enferm. 2013; 17(4): 753-62.

25. Parenti CF, Pereira LMR, Brandão ZS, Silvério APC. Perfil dos pacientes com AIDS acompanhados pelo Serviço de Assistência Domiciliar Terapêutica do Município de Contagem, Estado de Minas Gerais, Brasil, 2000-2003. Epidemiol Serv Saúde. 2005; 14(2):91-6.

26. Bajotto AP, Witter A, Mahmud SJ, Sirena S, Goldim JR. Perfil do paciente idoso atendido por um Programa de Atenção Domiciliar do Sistema Único de Saúde em Porto Alegre, RS. Rev HCPA. 2012; 32 (3): 311-17.

27. Toki A, Tamura R, Sumida M. Long-term ventilation for highlevel tetraplegia: a report of 2 cases of noninvasive positivepressure ventilation. Arch Phys Med Rehabil. 2008; 89:779-83.

28. Kaffashian S, Raina P, Oremus M, Pickard L, Adachi J, Papadimitropoulos $E$, et al. The burden of osteoporotic fractures beyond acute care: the Canadian Multicentre Osteoporosis Study (CaMos). Age Ageing. 2011; 40:602-7. 
29. Ansari K, Shamssain M, Farrow M, Keaney NP. Hospital-athome care for exacerbations of chronic obstructive pulmonary disease: an observational cohort study of patients managed in hospital or by nurse practitioners in the community. Chron Resp Dis. 2009; 6:69-74

30. Ettner SL, Conover CJ, Proescholdbell RJ, Weaver MR, Ang A, Arno PS. Triply-diagnosed patients in the HIVIAIDS Treatment Adherence, Health Outcomes and Cost Study: patterns of home care use. AIDS Care. 2008; 20 (10):1177-89.

31. Machado WCA., Scramin AP. (In)dependência funcional na dependente relação de homens tetraplégicos com seus (in) substituíveis pais/cuidadores. Rev Esc Enferm USP. 2010; 44 (1): 53-60.

32. Cattalini M, Prado SERD, Bellucci GA, Loli V, Vidal VGO, Errerias CC. Efeitos del atendimiento en domicílio sobre los marcadores bioquímicos y Los parametros biofisicos de pacientes con el síndrome metabólico. CuidArte Enfermagem. 2012; 6(1):15-23.

33. Sorbye LW, Hamran T, Henriksen N, Norberg A. Home care patients in four Nordic capitals - predictors of nursing home admission during one-year followup. J Multidiscip Healthcare. 2010; 3:11-18.

34. Del Duca GF, Thumé E, Hallal PC. Prevalência e fatores associados ao cuidado domiciliar a idosos. Rev Saude Pub. 2011; 45 (1): 11320.

35. Brondani CM, Ramos LH, Beuter M, Lampert MA, Seiffert MA, Bruinsma JL. Caracterização de pacientes dependentes de tecnologias de um serviço de internação domiciliar. Rev Enferm UFSM. 2014; 3(Esp.):689-99.

36. Tamir $O$, Singer $Y$, Shvartzman P. Taking care of terminally-ill patients at home - the economic perspective revisited. Palliative Medicine. 2007; 21:537-41.

37. Jagger C, Collerton JC, Davies K, Kingston A, Robinson LA, Eccles MP, et al. Capability and dependency in the Newcastle $85+$ cohort study. Projections of future care needs. BMC Geriatr 2011; 11:1-10

38. Rodríguez M. Use of informal and formal care among community dwelling dependent elderly in Spain. Eur J Public Health. 2013; 24(4):668-73

39. Gaspar JC, Campos Oliveira MA, Duayer MDFF. Perfil dos pacientes com perdas funcionais e dependência atendidos pelo PSF no município de São Paulo. Rev Esc Enferm USP. 2007; 41(4): 619-28

40. Almaawiy U, Pond GR, Sussman J, Brazil K, Seow H. Are family physician visits and continuity of care associated with acute care use at end-of-life? A population-based cohort study of homecare cancer patients. Palliative Medicine. 2015; 28 (2): 176-83.

41. Teno JM, Gozalo PL, Bynum JP, Leland NE, Miller SC, Morden $N E$, et al. Change in end-of-life care for medicare beneficiaries: site of death, place of care, and health care transitions in 2000, 2005, and 2009. 2013; 309(5): 470-7.
42. Fripp JC, Facchini LA, Silva SM. Caracterização de um programa de internação domiciliar e cuidados paliativos no município de Pelotas, estado do Rio Grande do Sul, Brasil: uma contribuição à atenção integral aos usuários com câncer no Sistema Único de Saúde, SUS. Epidemiol Serv Saúde. 2012; 21(1): 69-78.

43. Lacerda SM, Gazzola JM, Lopes AB, Lemos NDFD, Cordeiro RC. Qualidade de vida de idosos atendidos em programa de assistência domiciliária. Rev Bras Geriatr Gerontol. 2011; 14(2):329-42.

44. Ruiz-Miralles ML, Richart-Martínez M, Moreno-Pina JP, Villagrasa-Rocher F, Castroverde-Agudo O, Llopis-Cartagena $\mathrm{ML}$, et al. Estudio de la calidad de vida en las personas mayores confinadas en el domicílio en un barrio de Alicante. Enferm Clin. 2007; 17(6):287-92

45. Thumé E, Facchini LA, Wyshak G, Campbell P. The utilization of home care by the elderly in Brazil's primary health care system. Am J Pub Health. 2011; 101(5):868-74.

46. Rumbak I, Šatalić Z, Keser I, Panjkota Krbavčić I, Giljević Z, Zadro Z, Colić Barić I. Diet quality in elderly nursing home residents evaluated by Diet Quality Index Revised (DQI-R). Coll Antropol. 2010; 34(2):577-85

\section{Publish in International Archives of Medicine}

International Archives of Medicine is an open access journal publishing articles encompassing all aspects of medical science and clinical practice. IAM is considered a megajournal with independent sections on all areas of medicine. IAM is a really international journal with authors and board members from all around the world. The journal is widely indexed and classified Q2 in category Medicine. 